International Journal of Technology 12(1) 175-185 (2021)

Received July 2020 / Revised August 2020 / Accepted January 2021

International Journal of Technology

http://ijtech.eng.ui.ac.id

\title{
Energy and Exergy Analysis of Dieng Geothermal Power Plant
}

\author{
Alfian Hardi Qurrahman¹, Wahyu Wilopo ${ }^{1,2,3}$, Sigit Ponco Susanto ${ }^{4}$, Himawan Tri Bayu \\ Murti Petrus $1,3,5^{*}$
}

\begin{abstract}
${ }^{1}$ Master of System Engineering, Faculty of Engineering, Universitas Gadjah Mada, Yogyakarta 55281, Indonesia ${ }^{2}$ Departement of Geological Engineering, Faculty of Engineering, Universitas Gadjah Mada, Yogyakarta 55281, Indonesia

${ }^{3}$ Unconventional Georesources Research Center, Faculty of Engineering, Universitas Gadjah Mada, Yogyakarta 55281, Indonesia

${ }^{4}$ PT Geodipa Energi Unit Dieng, Wonosobo, Indonesia

${ }^{5}$ Departement of Chemical Engineering, Faculty of Engineering, Universitas Gadjah Mada, Yogyakarta 55281, Indonesia
\end{abstract}

\begin{abstract}
Energy and exergy analyses are conducted at the Dieng Geothermal Power Plant to determine the energy loss of components by calculating the efficiency, rate of change in energy flow, and exergy loss of each component. The data were collected on each component, including production wells, turbines, the main condenser, inter-condensers, and cooling towers, with the data collection occurring from April 2017 to March 2018. Energy and exergy analyses begin by calculating the enthalpy and entropy of both input and output from the compiled temperature data, with the help of a steam table. The study results show that the lowest efficiency was $67 \%$ in the turbine, and the highest energy change rate seen was $5.8 \times 10^{4} \mathrm{~kW}$, in the inter-condenser. In addition, the greatest exergy loss was $50 \mathrm{Mw}$, which occurred in the turbine, indicating it was the component most in need of repair. In summary, the study results clarified that the component that needed to be treated and repaired at the Dieng Geothermal Power Plant was the turbine.
\end{abstract}

Keywords: Dieng Geothermal Power Plant; Efficiency; Energy; Exergy

\section{Introduction}

The world's greatest geothermal potential of approximately $40 \%$ is located in Indonesia due to a concentration of high-temperature geothermal resources (Bina et al., 2018b). This geothermal potential is flattened along volcanic lines that run from the regions of Sumatra, Java, Nusa Tenggara, and Sulawesi to Maluku (Mary et al., 2017). The total potential geothermal power in Indonesia is 29,543 Mwe, consisting of resources of 11,997 Mwe and reserves of 17,546 Mwe (Ministry of Energy and Mineral Resources, 2015). However, this potential has not been successfully exploited, especially in power generation(Nasruddin. et al., 2016). It was estimated that in 2025, the installed capacity in Indonesia will only reach $9500 \mathrm{Mw}$ (Elfani, 2011), with only 4.5\% of the total exploited resources used as an electrical energy supply in Indonesia (Bina et al., 2018b). However, geothermal power plants can provide constant power based on the installed geothermal power plant capacity (Günther, 2018).

${ }^{*}$ Corresponding author's email: bayupetrus@ugm.ac.id, Tel.: +62-81327770497

doi: 10.14716/ijtech.v12i1.4218 
According to Eliasson et al. (2011), there are three types of geothermal systems, namely, the flash system characterized by a two-phase flow, the dry system characterized by a vapor-dominated flow, and a binary system characterized by a liquid-dominated flow. The Dieng Geothermal Power Plant in Dieng, Central Java, Indonesia, uses single-flash steam system technology, characterized by the use of large amounts of brine found in geothermal wells (Pambudi et al., 2014).

Energy and exergy analyses have been implemented numerous times in several studies due to the effectiveness of knowing the amount of energy reduction in a component (Dincer and Rosen, 2007). Dieng Geothermal Power Plant has experienced decreased energy in all its components. For example, the energy reduction in the turbine reached $11 \%$ of the energy input. The smallest energy reduction was $0.5-2 \%$ of the total energy in the input of the main condenser.

Nasruddin et al. (2018) conducted an exergy analysis and exergoeconomic optimization of the binary cycle system at Well Pad 4 of the Dieng Geothermal Power Plant using a multi-objective genetic algorithm. By applying the optimum parameters, the power plant had minimum values of total energy destruction of $742.4 \mathrm{~kW}$ and a total annual cost of 36,723 US dollars.

The organic Rankine cycle (ORC), with isopentane as the operating fluid, and the Kalina cycle, with an ammonia-water mixture, used in the system for power production at the geothermal power plant at Ampallas, West Sulawesi, were investigated by Nasruddin et al. (2020). They reported that the ORC system had the best exergy efficiency, at $82.12 \%$.

Similarly, energy and exergy analyses were conducted by Ulum et al. (2017) at the Mount Salak Geothermal Power Plant's Unit 1-2-3. They concluded that the largest exergy loss was recorded in the condenser, of around $27.84 \%$ of the total exergy of 302.42 MWe. Further, Rudiyanto et al. (2017) conducted an analysis at the Kamojang Geothermal Power Plant and reported that the system had an overall efficiency of $35.86 \%$ of the potential $309,000 \mathrm{~kW}$ being used. Exergy analysis has also been conducted at the Dieng Geothermal Power Plant by Pambudi et al. (2014). In that analysis, the greatest exergy losses were $13.5 \%$ in the separator and $12.94 \%$ in the turbine. Using thermodynamic analysis, Pambudi et al. (2015) showed that the performance of the geothermal power plant could be improved by changing from a single-flash system to a double-flash system.

However, a previous study by Pambudi et al. (2014) tended to focus on only four well pads and one month of data collection. In this study, the analysis is conducted for seven well pads, and data were collected for one year, from April 2017 through March 2018. The larger quantity of data used in the analysis process permitted a more thorough review and evaluation of the potential geothermal energy resources with the aim of increasing the total exploited energy in existing areas.

To achieve the study's goal, energy and exergy analyses were used in the study, and the results can be used to make improvements aimed at reaching the most favorable conditions by determining which components need to be repaired at the Dieng Geothermal Power Plant.

\section{Methods}

This Central Java province is part of the volcanic path in Indonesia. In this province, the Dieng Geothermal Power Plant is located in the Wonosobo district. The power plant's total size is $113,400 \mathrm{Ha}$. Dieng Geothermal Power Plant is an ideal location for a geothermal power plant due to the area's astonishing resources, including fumarole, solfatara, and hot springs (Ministry of Energy and Mineral Resources, 2017). 
Figure 1 shows the process flow diagram of the single-flash system of the Dieng Geothermal Power Plant's components. The figure shows the data collection points for the parameters pressure, temperature, and flow rate for each component, measured from March 2017 through February 2018. In 2017, there were five injection wells (Well Inject 17A, Well Inject 5A, Well Inject 9A, Well Inject 29A, and Well Inject 30A), and for production wells, there were seven units (Well Product 29, Well Product 7B, Well Product 7C, Well Product 30, Well Product 28A, Well Product 31, and Well Product 30).

Flow rate (F) was measured using a flow meter in the distributed control system (DCF), using a flow transmitter due to the pressure difference at the installed orifice. The temperature (T) parameter was measured using a variety of temperature instruments, including element temperature, bimetal, temperature gauge, and temperature transmitter. The pressure (P) at the power plant was measured using a pressure gauge and a pressure transmitter.

Pressure, temperature, and flow rate were measured in the production division (wells to the separator), with the temperature values measured at $100-190^{\circ} \mathrm{C}$, pressure of $9-10$ bars, and flow rate of 70-250 tons/hr., which is from two phases of flow in each well. The flow rate from the separator to the turbine was obtained from a steam flow of 20-150 tons/hr. In the power plant division, the recorded parameters were a flow rate of 250-350 $\mathrm{Kg} / \mathrm{s}$, pressure of $8-29$ bars, and temperature of $40-140^{\circ} \mathrm{C}$.

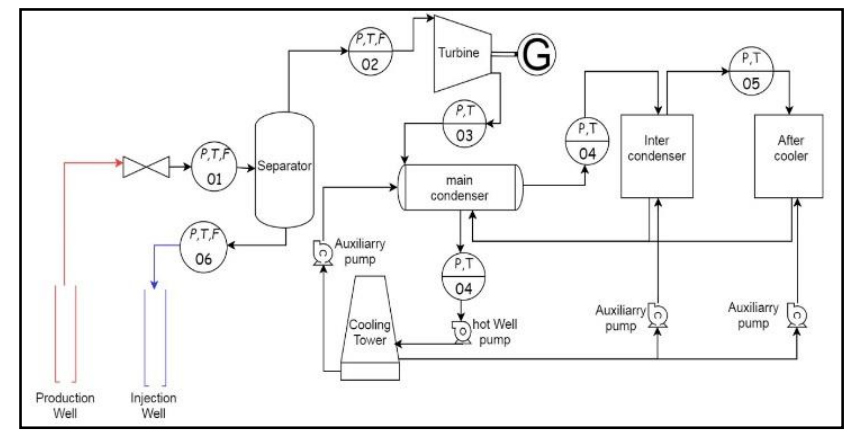

Figure 1 Schematic diagram of the single-flash system at Dieng Geothermal Power Plant

\subsection{Energy Analysis}

This study used the first and second laws of thermodynamics to calculate the energy and exergy losses in each component of the Dieng Geothermal Power Plant. The energy balance equation based on the first law thermodynamics can be expressed as shown in Equation 1 (Balta et al., 2010):

$$
\dot{E}_{\text {in }}-\dot{E}_{\text {out }}=\Delta \dot{E}_{s}
$$

where $\dot{E}_{\text {in }}, \dot{E}_{\text {out }}$, and $\Delta \dot{E}_{s}$ can be calculated using Equation 2:

$$
\dot{Q}-\dot{W}=\sum(\dot{m} h)_{\text {out }}-\sum(\dot{m} h)_{\text {in }}
$$

where $\dot{E}_{\text {in }}$ is the energy input, $\dot{E}_{\text {out }}$ is the energy output, $\Delta \dot{E}_{S}$ is the energy change rate, $\dot{Q}$ is the heat energy, $\Delta U$ is the energy change, $\dot{W}$ is the inner power, $\dot{m}$ is the mass flow rate, and $h$ is the specific enthalpy (Bina et al., 2018a).

The rate of energy change was measured for all of the Dieng Geothermal Power Plant's components, including the separator, turbine, condenser, after-cooler, and cooling tower, so that the results can be used for the evaluation of maintenance required on each of the components that are currently working less than optimally. 


\subsection{Efficiency of the Components}

The thermal efficiency of a turbine generator in a geothermal power plant system is defined as the power output from the turbine generator and the heat input entering into the turbine. Thermal efficiency of electricity can be expressed as shown in Equation 3 (DiPippo, 2015):

$$
\eta_{\text {thermal }}=\frac{\dot{W}_{e}}{\dot{Q}_{\text {input }}}
$$

Generally, the efficiency of a system can be determined by comparing the energy output and energy input according to Equation 4 (Yao et al., 2018).

$$
\eta_{\text {system }}=\frac{\dot{E}_{\text {output }}}{\dot{E}_{\text {input }}}
$$

Equation 3 was used to calculate the thermal efficiency of the turbine generator, and Equation 4 was used to calculate the efficiency of the main condenser, inter-condenser, and after-cooler components at the Dieng Geothermal Power Plant. The cooling tower efficiency was calculated by using Equation 5 (Damaputra et al., 2019).

$$
\eta_{\text {coolingtower }}=\frac{\dot{T}_{\text {range }}}{\dot{T}_{\text {range }}+\dot{T}_{\text {approach }}}
$$

where $\dot{T}_{\text {range }}$ is the difference in the temperature of the water entering the cooling tower and the water exiting the cooling tower, and $\dot{T}_{\text {approach }}$ is the difference in the temperature of the water exiting the cooling tower and the ambient temperature around the cooling tower.

\subsection{Exergy Analysis}

This study aimed to determine which of the components at the Dieng Geothermal Power Plant were creating the greatest energy loss by conducting an exergy analysis. The exergy equation is based on the second law of thermodynamics and can be expressed as shown in Equation 6 (Gökgedik et al., 2016).

$$
E_{t}=\dot{m}\left[\left(h_{t}-h_{0}\right)-T_{0}\left(s_{t}-s_{0}\right)\right]
$$

where $E_{t}$ is exergy, $\dot{m}$ is mass flow rate, $h$ is enthalpy, $h_{0}$ is enthalpy at the ambient temperature and pressure, $T_{0}$ is the ambient temperature, $s$ is the entropy of operating conditions, and $s_{0}$ is the entropy at the ambient temperature and pressure.

\section{Results and Discussion}

Mass balance is the amount of fluid flow and the steam content of the fluid entering and exiting a turbine. Figure 2 shows the results, indicating a mass balance, which shows there was no loss of mass flow in the turbine.

On May 19 and October 1-4, 2017, a low mass flow rate value was recorded, and the recorded flow rate on the turbine was also low. The lowest recorded mass flow rates were 265 and 256 ton/hr. There are several causes for the low flow rate in the turbine; the first is the loss of steam mass from the well to the plant, and the second is damage to the flow rate recorder device in the turbine.

\subsection{Energy Analysis}

In the energy analysis, based on the first law of thermodynamics, the rate of change in energy flow is the difference between the input and the output of the energy flow rate. The first law of thermodynamics states that energy cannot be created or destroyed and can only be changed into other forms of energy. The energy analysis of the Dieng Geothermal Power 
Plant was completed only in the power plant division and included the turbine generators, main condenser, inter-condenser, and cooling tower.

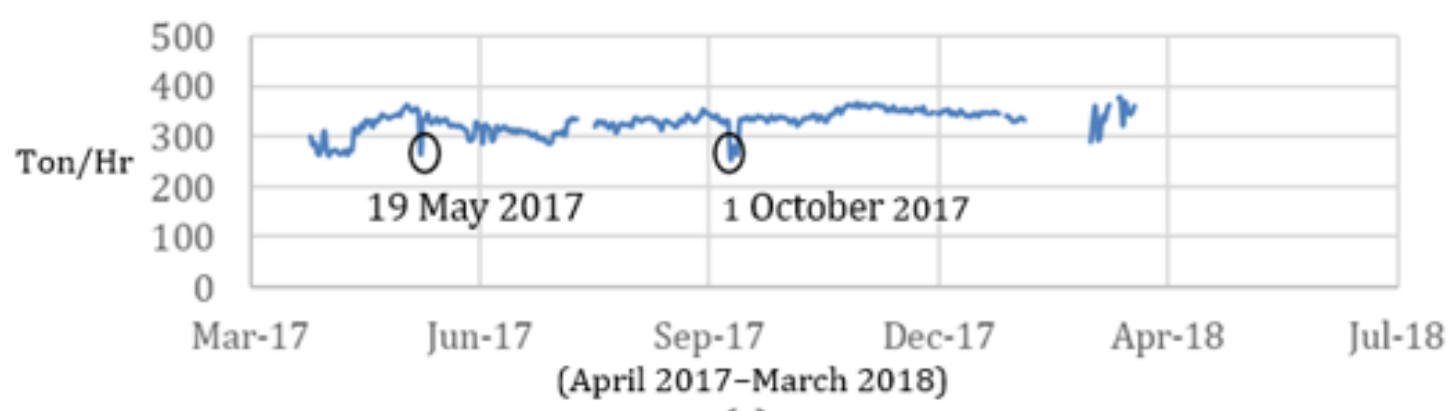

(a)

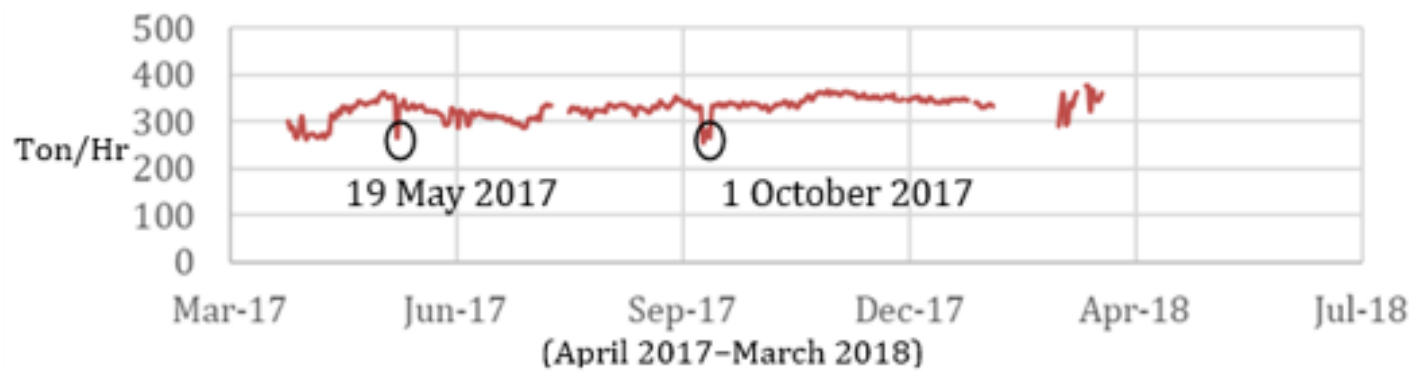

(b)

Figure 2 Profile of mass balance at the turbine: (a) input; and (b) output at Dieng Geothermal Power Plant

\subsubsection{Turbine generator}

Figure 3 shows a profile of the energy flow rates, and it can be seen that there was a difference between the input and output energy (positive), consisting of the difference between the heat and the effort made by the system (turbine). The average difference in the rate of energy change was 19-21 Mw, with the highest value of $24 \mathrm{Mw}$ and the lowest value of $15 \mathrm{Mw}$. The lowest value is smaller than the turbine energy rate found the Kamojang Geothermal Power Plant, which was 62.7 Mw (Rudiyanto et al., 2017). This value is influenced by the mass flow rate, which is proportional to the energy flow rate. In addition, the difference between the input and output temperatures also affects the change in energy rate. At the Kamojang Geothermal Power Plant, the mass flow rate and the temperature input at the turbine were greater than those measured at the Dieng Geothermal Power Plant. This was because the Kamojang Geothermal Power Plant has greater power capacity than the Dieng Geothermal Power Plant.

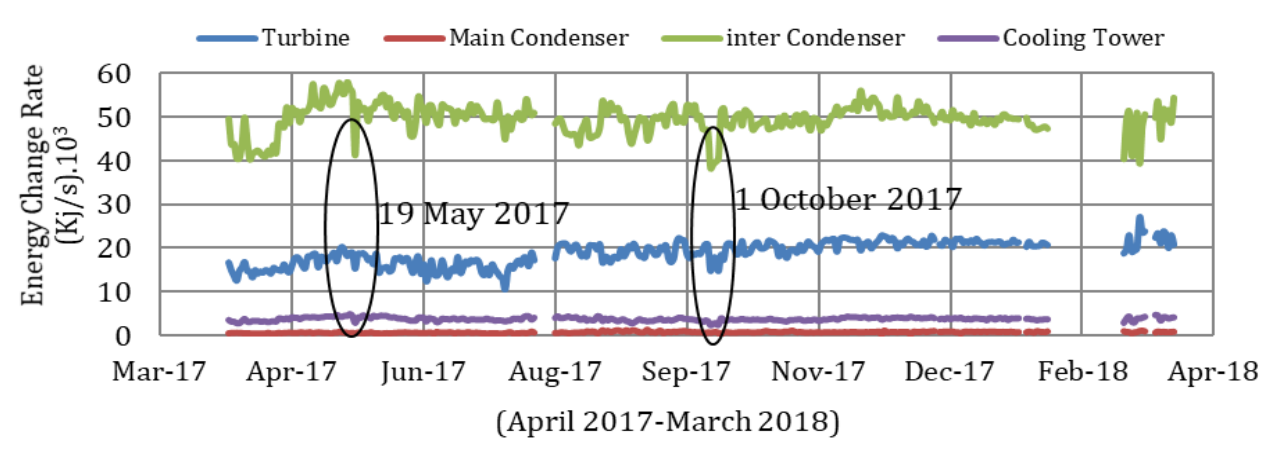

Figure 3 Profile of energy flow rate of all components at Dieng Geothermal Power Plant 


\subsubsection{Main condenser}

The value of the energy flow rate was obtained in the main condenser at the input and output of each component. The results showed that all the components had almost the same values at the input and output; therefore, the energy rate changes occurring in these components are constant. The value indicated a small change in energy flow rate at the main condenser, indicating that the component was doing little work because the rate of energy change in the main condenser was very low, with an average value of less than $1 \mathrm{Mw}$.

The input and output flow rate profile in the main condenser of the Dieng Geothermal Power Plant is provided in Figure 3. The energy rate measured during the study at the Dieng Geothermal Power Plant was between $150 \mathrm{Mw}$ and $220 \mathrm{Mw}$, which is smaller than the Kamojang Geothermal Power Plant's dry steam system, measured at $247 \mathrm{Mw}$ (Rudiyanto et al., 2017). The difference is due to the low mass flow rate at the Dieng Geothermal Power Plant.

\subsubsection{Inter-condenser}

Figure 3 also provides the inter-condenser mass flow rate profile. Here, there was a large gap between the input and output flow rates; therefore, the change in the flow rate of the component is also large. The gap in energy rates in the inter-condenser at the Dieng Geothermal Power Plant exceeded $40 \mathrm{Mw}$, which is much greater than the measurement taken in the dry steam system at the Kamojang Geothermal Power Plant of $4 \mathrm{Mw}$ (Rudiyanto et al., 2017). This is because the mass flow rate input at Kamojang $(2,257 \mathrm{Kg} / \mathrm{s})$ is $1 / 30$ the mass flow rate at Dieng $(71 \mathrm{Kg} / \mathrm{s})$. When the work level in the inter-condenser at the Dieng Geothermal Power Plant is greater, the level of non-condensable gas (NCG) discharged into the air becomes low.

\subsubsection{Cooling tower}

The input and output flow rates measured in the cooling tower are also provided in Figure 3. Rudiyanto et al. (2017) reported that the cooling tower energy rate in the Kamojang Geothermal Power Plant's dry steam system was 291,778.2 kW, which was greater than the measurement taken in the Dieng Geothermal Power Plant's single-flash system $(160,000 \mathrm{~kW})$. This is because the mass flow rate at the Kamojang Geothermal Power Plant was high. At Dieng, the energy flow rates of all the components experienced a decrease in both input and output between May 19 and October 1-4, 2017, because of the loss of steam mass flow in the pipes from the well, before entering the turbine, followed the energy balance, as shown in Figure 2.

\subsection{Efficiency of the Components}

\subsubsection{Turbine generator}

Figure 4a presents the thermal efficiency of the turbine generator as calculated using Equation 3, where the thermal efficiency of a turbine generator is a ratio between the heat that enters the turbine and the net output power of the generator.

The average thermal efficiency of the Dieng Geothermal Power Plant's turbine generator is provided in Figure 4a. The thermal efficiency was greater than what is recommended, which is a range values from 60\% to $80 \%$ (Zarrouk and Moon, 2014), while the turbine generator's thermal efficiency was measured at between $70 \%$ and $85 \%$. At the lowest conditions, around May 19, 2017, the power plant efficiency was around $60 \%$ due to the low incoming fluid flow in the turbine. It was also low on July 25,2017 , due to the quality of steam (steam temperature) entering the turbine, which was also low, and on October 1, 2017, it was low due to low fluid flow into the turbine. Efficiency values that exceed $90 \%$ are caused by the low incoming flow rate of the turbine, but the power conversion is obtained at large generators. 


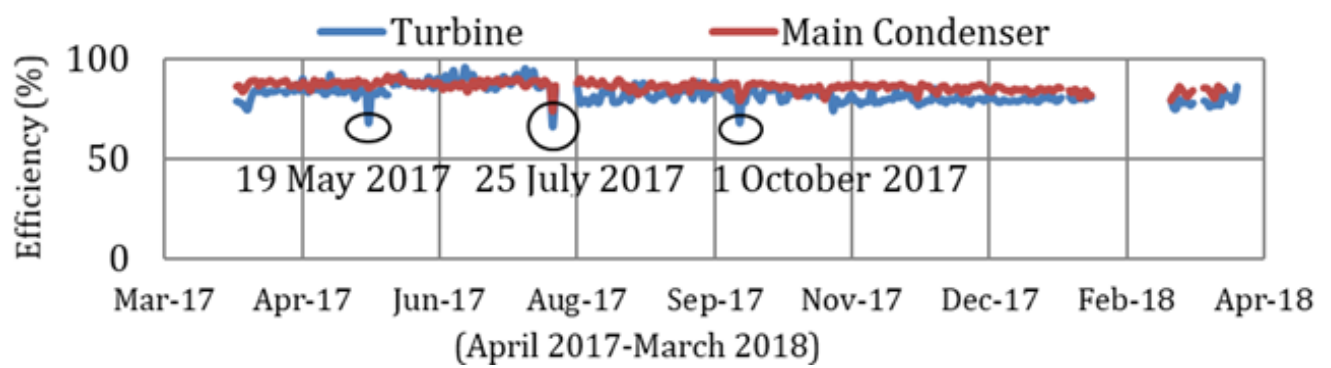

(a)

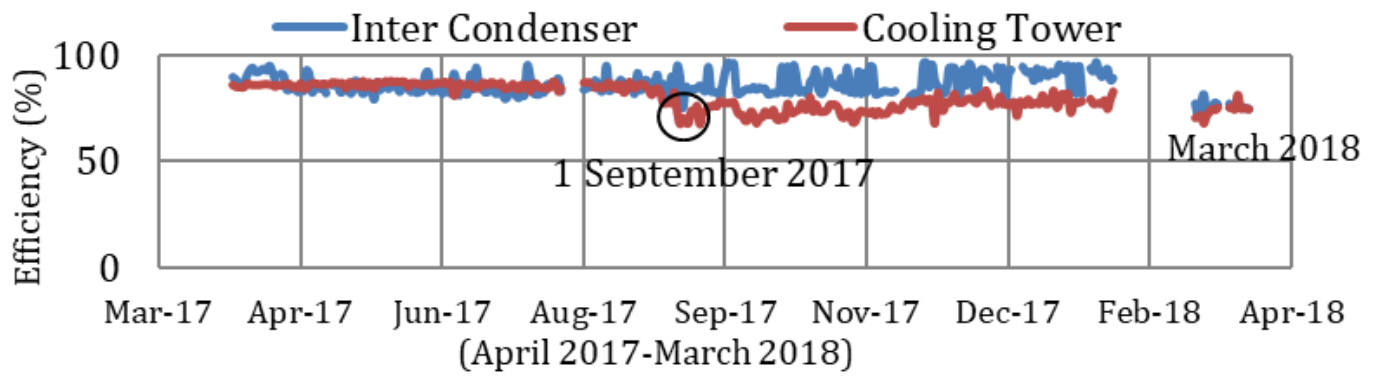

(b)

Figure 4 The efficiency profile of the: (a) turbine and main condenser; and (b) inter-condenser and cooling tower at Dieng Geothermal Power Plant

\subsubsection{Main condenser}

The condenser efficiency is the ratio between heat coming in and out of the system. The main function of the condenser is to condense the steam that has been used to drive the turbine. The efficiency of the condenser indicates how fast the condenser converts steam coming from the turbine into condensate material and how much material is converted. Figure 4a shows the measurement of efficiency taken in the Dieng Geothermal Power Plant's condenser, where the value of the main condenser was, on average, around 80-90\%. Figure 4a shows that there was an efficiency value for the main condenser of $72 \%$ on July 25,2017 . This was caused by the temperature of the incoming steam being lower than the incoming steam's temperature in normal circumstances. As a result of the low temperature, the final condensate temperature in the main condenser was also lower. The energy loss of all condensers (main condenser and inter-condenser) at the Dora-1 and Dora-2 Geothermal Power Plants, as measured by Yildirim and Ozgener (2012), was the same at our measurements at the Dieng Geothermal Power Plant, which was $40 \%$ to $50 \%$. The main and inter-condenser efficiencies at the Dieng Geothermal Power Plant condensers were 80\%.

\subsubsection{Inter-condenser}

The function of the inter-condenser is to condense the NCG that cannot be condensed by the main condenser. The efficiency of the inter-condenser is the ratio between the incoming and outgoing heat in the inter-condenser. Figure $4 \mathrm{~b}$ shows the efficiency of the inter-condenser at the Dieng Geothermal Power Plant.

It can be seen that the inter-condenser's efficiency was measured in a range between $80 \%$ and $90 \%$. However, there were efficiency rates below 80\% in March 2018. This condition occurs when there is a large gap between the condensate temperature entering from the main condenser and the temperature of the condensate coming out of the condenser. The smaller the temperature gap between the incoming and outcoming condensates, the greater the efficiency obtained. When the incoming condensate temperature is the same as the outgoing condensate temperature, it means that less of the steam contained in the NCGs being condensed by the inter-condenser becomes condensate. 


\subsubsection{Cooling tower}

The cooling tower is a heat exchanger component of a geothermal power plant that functions to cool water by connecting it with the surrounding air. The efficiency of the cooling tower is determined by analyzing the effectiveness using the range and approach given in Equation 5. Damaputra et al. (2019) reported that the efficiency value of the cooling tower component at the Kamojang Geothermal Power Plant was 64.62\% lower than the measurement taken at the Dieng Geothermal Power Plant. This difference is because of the lower temperature input, lower temperature output, and lower environmental temperature around the Dieng Geothermal Power Plant $\left(17^{\circ} \mathrm{C}\right)$. The most important factor is that there is a smaller difference in the temperature output and the environmental temperature. Figure $4 \mathrm{~b}$ shows a high range of values showing efficiency above $85 \%$. However, the cooling tower's performance will be better if the approach value is smaller. In Figure 4 b, a high approach value results in an efficiency value of 70-80\% on September 1, 2017. This was caused by a decreased range value, while the value of the approach remained constant.

\subsection{Exergy Analysis}

Exergy analysis was conducted on the entire Dieng Geothermal Power Plant, from the input to the exergy output in each component, including the separators, turbines, condensers, cooling towers, and brines. Exergy for each component is determined by using Equation 6.

\subsubsection{Exergy input}

Exergy is generally used to find heat loss; therefore, the use of energy from a thermal system input becomes more efficient. At the Dieng Geothermal Power Plant, the amount of exergy input from thermal sources in the bowels of the earth was measured as a range from $100 \mathrm{Mw}$ to $140 \mathrm{Mw}$. The exergy input value is the total exergy value of each well pad. On average, each well pad is measured at only around 10-20 Mw, but there is one well pad, Well Pad 30, which has an exergy input value of 30-40 Mw. Pambudi et al. (2014) reported that the exergy value of the resulting input was only $60 \mathrm{Mw}$, while in 2017, the exergy value of input increased to almost $140 \mathrm{Mw}$. This was because of the addition of new wells prompted by the study by Pambudi et al. (2014). As a result, the Pambudi et al. (2014) study researched only four well pads, while in this study, there were seven wells being researched.

\subsubsection{Exergy losses in the separator}

In the separator, the exergy value measured showed a loss gap between the exergy input at the thermal source and the output at the separator. Figure 5 shows the exergy loss in the separator at the Dieng Geothermal Power Plant from April 2017 to March 2018, with a value of $10 \mathrm{Mw}$ to $30 \mathrm{Mw}$ more than the measurements taken for Pambudi et al. (2014)'s research in 2014 at the same location. The addition of the well pads is the most influential factor in changing the exergy input, exergy output, and exergy loss. The exergy losses in the separator measured the highest value at $27 \mathrm{Mw}$ and the lowest at $14 \mathrm{Mw}$. The average value of exergy loss is in the range of 15-25 Mw, which was a continuous increase from April 2017 through March 2018.

\subsubsection{Exergy losses in the turbine}

Turbines are the most important component in a power generation system, and the geothermal power system is no exception. The exergy loss in the turbine is calculated from the difference between exergy input and exergy output. Pambudi et al. (2014) recorded an exergy loss in the turbine of 7.5 Mw, while the turbine exergy loss in April 2017 through March 2018 was from $30 \mathrm{Mw}$ to $50 \mathrm{Mw}$, a twofold measurement compared to that taken by 
Pambudi et al. (2014). The highest measurement of exergy loss in 2017 was influenced by the temperature of the steam input of $187^{\circ} \mathrm{C}$ higher than the average temperature of steam entering the turbine. On July 15, 2017, and October 1-5, 2017, the exergy loss in the turbine decreased to a value of $27 \mathrm{Mw}$. This was because the temperature of the steam entering the turbine was very low and was followed by the mass flow entering the turbine as well. This amount of exergy loss indicated that the component did not work optimally. At the Dieng Geothermal Power Plant, the turbine showed the highest levels of exergy loss. This exergy loss can be minimized by reducing the temperature of the steam entering the turbine or increasing the temperature of the steam output from the turbine.

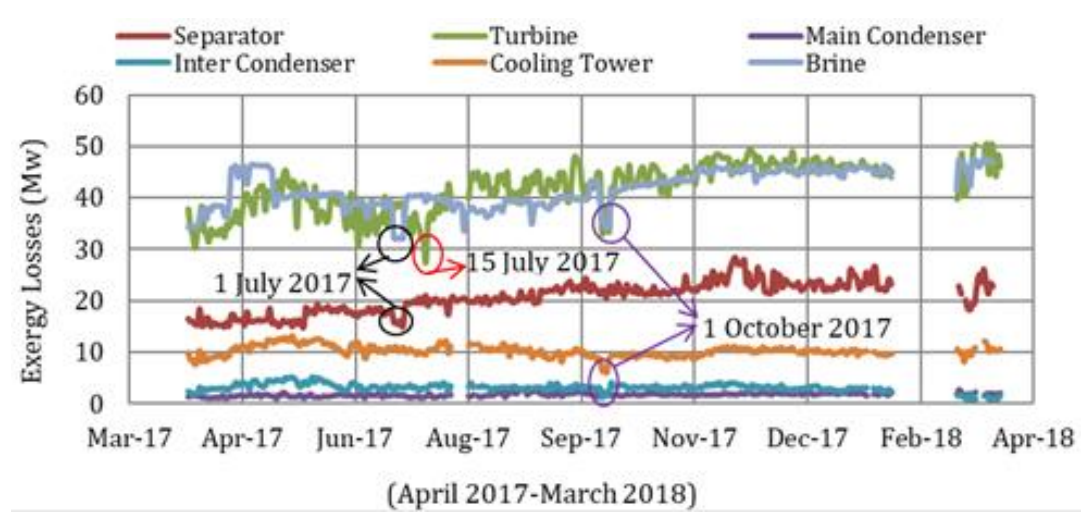

Figure 5 Profile of exergy losses from all components at the Dieng Geothermal Power Plant

\subsubsection{Exergy losses in the main condenser}

Figure 5 shows the exergy losses in the main condenser, with an average value of $1-$ $2 \mathrm{Mw}$. These exergy losses were lower than those recorded in 2014, which was $3.43 \mathrm{Mw}$ (Pambudi et al., 2014). This means that the performance of the main condenser in transferring heat from the input to output exergy from April 2017 to March 2018 was better than the condenser's performance in 2014. The loss of energy exceeded $2 \mathrm{Mw}$ from late August 2017 to early September 2017 because of the large gap between the main condenser's input temperature and the condenser's output temperature. However, this value was not significant in comparison to the average value of exergy loss in the component.

\subsubsection{Exergy losses in the inter-condenser}

When exergy losses are experienced in the main condenser, they are also experienced in the inter-condenser. Pambudi et al. (2014) reported that the exergy loss in the intercondenser was $0.93 \mathrm{Mw}$, which was lower than this study's measurement of 1-5 Mw. However, it is not too significant in comparison to the exergy values of input and output shown in Figure 5. On October 1, 2017, the value of exergy loss in the inter-condenser was lower than the prior few months, which was $1.3 \mathrm{Mw}$, because the mass flow came in below 300 tons/day. In March 2018, the exergy loss was very low because the temperature and enthalpy of the input to the inter-condenser were almost the same as the temperature and enthalpy of the inter-condenser output.

\subsubsection{Exergy losses in the cooling tower}

The last component that was considered in the measure of exergy loss was the cooling tower, where the condensate cools from the main condenser before being finally transferred back to the condenser. The measured cooling tower exergy loss values can be seen in Figure 5. The value of exergy loss in the cooling tower was a range of 8-10 Mw, which is greater than Pambudi et al.'s (2014) measurement of 2.62 Mw. However, there are some points that reached $6 \mathrm{Mw}$ on October $1-3,2017$. This is caused by the flow rate that 
entered the cooling tower being lower than most of the incoming flow rate values, even the 2014 flow rate, which generally entered the cooling tower at a lower flow rate than in 2017.

\subsubsection{Exergy losses in the brine}

The brine geothermal power plants also experienced exergy losses, which can be seen in Figure 5. The exergy loss to the brine was 30-45 Mw which is large enough to reduce the value of exergy entering the turbine. Pambudi et al. (2014) reported exergy loss from the brine was $10.7 \mathrm{Mw}$, while in the present study, the exergy loss increased twofold. On July $1-5,2017$, the value of exergy loss in the brine was lower than the value of exergy loss at the end of June 2017. The reduction in exergy loss was caused by the increase in output temperature. However, the flow rate value remained the same as at the end of June, whereas after July 5 , flow rate values increased according to the increase in output temperature.

\section{Conclusions}

The major change in the energy flow rate at the Dieng Geothermal Power Plant occurred in the condenser, which had the highest value of $5.8 \times 10^{4} \mathrm{~kW}$. This was because the incoming temperature was lower than the outgoing temperature in the inter-condenser. The Dieng Geothermal Power Plant's turbine efficiency was between $70 \%$ and $80 \%$, which is still in the reliable category according to the reference between $60 \%$ and $80 \%$. The efficiency of the cooling towers remained good from April 2017 to August 2017, with values above $80 \%$. However, it decreased in September 2017 to $70 \%$. The highest exergy loss that occurred in the turbine was $50 \mathrm{Mw}$. This was because the incoming steam temperature was still quite high, so the energy content in the turbine was excessive. In conclusion, the Dieng Geothermal Power Plant has to reduce the incoming steam temperature to the turbine in order to reduce the exergy loss. This would result in the power generated by the generator increasing.

\section{Acknowledgements}

The authors would like to thank PT Geodipa Energy Unit Dieng for their support and for the data they provided. The authors would also like to thank Universitas Gadjah Mada for the support.

\section{References}

Balta, M.T., Dincer, I., Hepbasli, A., 2010. Energy and Exergy Analyses of a New Four-Step Copper-Chlorine Cycle for Geothermal-Based Hydrogen Production. Energy, Volume 35(8), pp. 3263-3272

Bina, S.M., Jalilinasrabady, S., Fujii, H., 2018a. Exergoeconomic Analysis and Optimization of Single and Double Flash Cycles for Sabalan Geothermal Power Plant. Geothermics, Volume 72, pp. 74-82

Bina, S.M., Jalilinasrabady, S., Fujii, H., Pambudi, N.A., 2018b. Classification of Geothermal Resources in Indonesia by Applying Exergy Concept. Renewable and Sustainable Energy Reviews, Volume 93, pp. 499-506

Damaputra, M.K., Rachmat, A., Koswara, E., 2019. Cooling Tower Unit 3 Efficiency Comparison and Cooling Process in PT. Indonesia Power Generation Unit and Generation Services (UPJP) Kamojang, pp. 43-46

Dincer, I., Rosen, M.A., 2007. Exergy: Energy, Environment and Sustainable Development. Elsevier Ltd., Philadelphia, PA, USA

DiPippo, R., 2015. Geothermal Power Plants: Principles, Applications, Case Studies and Environmental Impact. 4th Edition. Butterworth-Heinemann, Oxford, UK 
Elfani, M., 2011. The Impact of Renewable Energy on Employment in Indonesia. International Journal of Technology, Volume 2(1), pp. 47-55

Eliasson, E. T., Thorhallsson, S., \& Steingrímsson, B. (2011). Geothermal power plants. Presented at "Short Course on Geothermal Drilling, Resource Development and Power Plants", Organized by UNU-GTP and LaGeo, in Santa Tecla, El Salvador, 16-22.

Gökgedik, H., Yürüsoy, M., Keçebaş, A., 2016. Improvement Potential of a Real Geothermal Power Plant using Advanced Exergy Analysis. Energy, Volume 112, pp. 254-263

Günther, M., 2018. Challenges of a 100\% Renewable Energy Supply in the Java-Bali Grid. International Journal of Technology, Volume 9(2), pp. 257-266

Mary, R.T., Armawi, A., Hadna, A.H., Pitoyo, A.J., 2017. Geothermal as a Treasure towards National Energy Resilience. National Defence, Volume 23(2), pp. 93-113

Ministry of Energy and Mineral Resources, 2017. Indonesia Geothermal Potential. Jakarta, Indonesia

Ministry of Energy and Mineral Resources, 2015. Strategic Plan of the Ministry of Energy and Mineral Resources for 2015-2019. Jakarta, Indonesia

Nasruddin, N., Alhamid, M.I., Daud, Y., Surachman, A., Sugiyono, A., Aditya, H.B., Mahlia, T.M., 2016. Potential of Geothermal Energy for Electricity Generation in Indonesia: A Review. Renewable and Sustainable Energy Reviews, Volume 53, pp. 733-740

Nasruddin, N., Nasution, S., Aisyah, N., Surachman, A., Wibowo, A.S., 2018. Exergy Analysis and Exergoeconomic Optimization of a Binary Cycle System using a Multi Objective Genetic Algorithm. International Journal of Technology, Volume 9(2), pp. 275-286

Nasruddin, N., Dwi Saputra, I., Mentari, T., Bardow, A., Marcelina, O., Berlin, S., 2020. Exergy, Exergoeconomic, and Exergoenvironmental Optimization of the Geothermal Binary Cycle Power Plant at Ampallas, West Sulawesi, Indonesia. Thermal Science and Engineering Progress, Volume 19, 100625

Pambudi, N.A., Itoi, R., Jalilinasrabady, S., Jaelani, K., 2014. Exergy Analysis and Optimization of Dieng Single-Flash Geothermal Power Plant. Energy Conversion and Management, Volume 78, pp. 405-411

Pambudi, N.A., Itoi, R., Jalilinasrabady, S., Jaelani, K., 2015. Performance Improvement of a Single-Flash Geothermal Power Plant in Dieng, Indonesia, Upon Conversion to a Double-Flash System using Thermodynamic Analysis. Renewable Energy, Volume 80, pp. 424-431

Rudiyanto, B., Illah, I., Pambudi, N.A., Cheng, C.C., Adiprana, R., Imran, M., Huat Saw, L., Handogo, R., 2017. Preliminary Analysis of Dry-Steam Geothermal Power Plant by Employing Exergy Assessment: Case Study in Kamojang Geothermal Power Plant, Indonesia. Case Studies in Thermal Engineering, Volume 10, pp. 292-301

Ulum, B., Nurrohman, N., Ambarita, E., Gaos, Y.S., 2017. Energy and Exergy Analysis of Mount Salak Geothermal Power Plant Unit 1-2-3. International Journal of Technology, Volume 8(7), pp. 1217-1228

Yao, S., Zhang, Y., Yu, X., 2018. Thermo-Economic Analysis of a Novel Power Generation System Integrating a Natural Gas Expansion Plant with a Geothermal ORC in Tianjin, China. Energy, Volume 164, pp. 602-614

Zarrouk, S.J., Moon, H., 2014. Efficiency of Geothermal Power Plants: A Worldwide Review. Geothermics, Volume 51, pp. 142-153 